28

人民战争

People's War

GUAN Kai

(Translated by Christian SORACE)

The richest source of power to wage war lies in the masses of the people.

It is mainly because of the unorganised state of the Chinese masses that Japan dares to bully us. When this defect is remedied, then the Japanese aggressor, like a mad bull crashing into a ring of flames, will be surrounded by hundred of millions of our people standing upright, the mere sound of their voices will strike terror into him, and he will be burned to death.

Mao Zedong, ‘On Protracted War', 1938

I

n 1938, as Japan's war machine and total invasion of China clearly advanced, and the Chinese army suffered defeat in every battle, the entire country was pervaded by the anxiety and premonition of defeat. Given the conspicuous lack of national and military strength at the time, China seemed to have no other road than surrender.

In May 1938, Mao published 'On Protracted War', rich with a vision of the future that firmly predicted China's ultimate victory in the War of Resistance against Japan (1937-45). According to him, the 'magic weapon' (fabao) that would deliver victory to China was guerrilla warfare. But the ability to engage in guerrilla warfare for an unknown duration of time depended on the support of the people in the countryside. In Mao's words, 'the [people] may be likened to water, the [guerrilla soldiers] to the fish who inhabit it'-later aphorised as 'the people are the sea that the revolutionary swims in. The metaphor of a fish in water describes an intimate political relationship and ecology in which the Communist Party (CCP) lives among the people. Thus, 'guerrilla war' (youji zhan) and 'protracted war' (chijiu zhan) were more than mere military strategies, as they constituted a broad outlook that Mao referred to as 'people's war' (renmin zhanzheng). For Mao, people's war was not only a blueprint for victory against the Japanese but a source of political legitimacy. In August 1946, after the victory against Japan, Mao said to the American reporter Anna Louise Strong: 'The outcome of a war is decided by the people.' ${ }^{1}$ One does not have to strain too hard to hear echoes 
of Mencius's political philosophy: 'The time is not as important as the terrain, and the terrain is not as important as having unity with the people ... [A]n unjust cause finds little support.'

\section{Who Are the People?}

To understand people's war, it is imperative to raise the conceptually thorny question: who are 'the people' (renmin)?

In China's history, there has never been a concept of the people-only the binary structure of government officials and ordinary people. In traditional Chinese thought, the minority of rulers-'officials' (guan) — and the majority who are ruled-'people' ( $\mathrm{min}$ ) - are both separated and connected by a material force, which confirms the truth that people are the material foundation of rule. This idea is articulated in the wellknown Chinese expression that the 'water can carry the boat or overturn it.'

The concept of the people originated from the French Revolution (1789-99) and the transformation of monarchical subjects into the subject of popular sovereignty of the nation-state. ${ }^{2}$ After the emergence of the modern nation-state-alongside other basic factors, such as territory, sovereignty, population, and government-the vague concept of the people was elevated to the ruler of the nation. Marxist theory was suspicious of such a slippery concept. From a Marxist perspective the state is an instrument of the ruling class; in this light, the people function as a vague concept that conceals class antagonism. The Marxist worldview of class antagonism between the proletariat and the bourgeoisie does not include the category of the people. So how did the people arrive on the stage in China?

The people is a fundamentally abstract concept-what Ernesto Laclau referred to as an 'empty signifier,' the meaning of which is determined by how it is inserted into a particular context. ${ }^{3}$ Under the ideological control of the Leninist political party, the people can be transformed into a flexible and pliable object of political manipulation. On the one hand, the people is the faintly discernible trace of revolutionary practice, a slogan that can be found everywhere, but the meaning of which is constantly changing. On the other hand, the people takes on particular meanings in different contexts in order to satisfy the needs of political reality. For example, in the War of Resistance against Japan, the revolutionary objective was the country's independence and national liberation: the Chinese people (zhonghua minzu) as a national category were equivalent to the people of China as a political category. After the CCP obtained political power, the category of the people was reformulated. Anyone who endorsed the socialist path belonged to the people, and anyone who opposed it became an 'enemy of the people.' The fulcrum of internal political struggle was the distinction between 'contradictions among the people' (remin neibu maodun) and 'contradictions between ourselves and the enemy' (diwo maodun) (see the essays by Rojas and Dutton in the present volume). The differentiation of political community is the foundation and prerogative of the CCP's leadership.

The abstract concept of the people always requires a supplement to make it concrete. For this reason, it is necessary to examine in fine-grained detail the different historical moments and discourses in which the name of the people was invoked. 


\section{People's War or Peasant's War?}

Under the conditions in which military strength was insufficient for victory, the CCP's army did not solely rely on military strategy, but simultaneously applied a political strategy. A slogan of this strategy was 'to win the war, rely on the people for support.' Due to its dependence on the people for victory, the army of the CCP referred to itself as 'the people's army' (renmin zidi bing) - a term that semantically implies that the army is the child of the people-and proclaimed its mission to fight on behalf of the interests of the 'the broad masses of the people' (guangda renmin qunzhong).

But in China at the time, the peasantry was the country's largest demographic. The CCP won the peasantry's support by identifying, addressing, and resolving their needs and aspirations, at the same time as it set up military encampments in the countryside. If communism is said to be a utopia, the CCP's revolutionary policy of land reform was far from an ideologically misty affair. Rather, it was a practical political endeavour, which severed the roots of the existing social system. The CCP's Marxist message and promise of the communist future was enthusiastically received by the peasantry who understood it through a Confucian framework of social equality in which the elite and the lowly, the rich and the poor are [treated] the same.' Confucian morality was draped in the attire of modernity and Marxist social equality. The majority of Chinese people fully supported the CCP's War of Resistance against Japan because they saw the land reform being carried out in communist-controlled areas as containing the seeds of their emancipation-a potential future when they could become the masters of their own lives. To defend the land parcels allocated to them by the CCP, the masses were willing to risk and sacrifice everything, and 'give their last grain of rice for army provisions, last piece of cloth for military uniforms, last bed frame as a coffin lid, and send their last son to the troops.' ${ }^{\text {' }}$ Under the historical magnifying glass, the people were revealed to be none other than the peasantry.

Mao realised that the Chinese revolutionary war depended on the correct handling of the peasantry and the ability to resolve their problems (see Day's essay in the present volume), and could not rely on the classical definition of the proletariat. From the earliest periods of his thinking, Mao's call to 'strike local tyrants and redistribute the land' ( $d a$ tuhao, fen tiandi) became the basis of revolutionary policy. Whereas this practice was successful in the early years in the base of operations in the Jinggang Mountains and Jiangxi Soviet (1931-34), it later had to be modified to fit the changing political situation.

After arrival in Yan'an in 1935, the CCP adjusted its land policy to call upon the peasantry to 'pay rent and interest' (jiao zu jiao $x i$ ) and for landlords to 'decrease rent and interest' (jian zu jian $x i$ ) in order to ameliorate the impact of class contradiction. This was because Mao regarded the War of Resistance against Japan as a historical mission of national liberation, and wanted to mobilise the political capabilities of the entire nation. In other words, class warfare had to take a backseat to national liberation. The results of this decision were fruitful. To synthesise the precarious balance between class and national objectives, the CCP invented different political forms, such as: the democratic regime of the 'three-thirds system;' the absorption of 'enlightened gentlemen' (kaiming shenshi) into the struggle for national liberation; the invention of a ballot mechanism based on the 'selection of representatives by the casting of bean 
shoots; and the establishment of a democratic system of government that was a bright lantern in the darkness. ${ }^{5}$ In all of China at that time, the mountain pagoda of Yan'an was the most politically attractive place.

Mao's people's war was conducted by the peasantry-but this fact is often obscured by the common definition of the peasantry as narrow-minded and incapable of class consciousness and class affection. But the CCP's concept and practice of people's war and the united front (see De Giorgi's essay in the present volume) supplemented the limited scope and class exclusivity of the original principles of Marxist-Leninist theory, while maintaining the organisational structure and mobilisational character of the Leninist political party. The inclusion of the peasantry expanded the CCP's social base of mobilisation, and formed unique political traditions, such as the centralisation of power to achieve major goals and the ability to launch political movements to solve political and social problems, which deeply influenced modern China.

\section{People's War or National War?}

The war of national liberation was considered a stepping stone on the road to class emancipation. But could these logics be so neatly disentangled?

The interests of the oppressed classes and oppressed nations are the motor of the development of human history. People's war came into being as part of the resistance against oppression. Mao traced the concept of people's war along a lineage of resistance, including examples from Chinese history, the slave revolt led by Spartacus against the Romans, and the early nineteenth-century wars of national resistance across Europe against Napoleon. In communist ideology, for the true nature of people's war to be revealed, it needed to first separate itself from the category of national war and transcend the principle of national self-determination-only then could the people obtain a class basis, and gain the long-term support of the oppressed classes of the world-the dream of international communist solidarity.

But for the CCP to achieve victory over the Japanese, it needed to mobilise the support of the entire nation, and not just the industrial working class (who barely existed as a class at that time). The category of the people was expanded to ventilate the contradictions of Chinese society. Mao invoked the name of the people to transform the CCP into the core leadership of the Chinese Revolution, construct the political party itself through the 'mass line' (see Lin Chun's essay in the present volume), and establish itself as the founder and leader of the emancipation of the Chinese peopleand not only serve as a local branch of the Comintern. Although the CCP called itself a class party, people's war transcended the narrow boundaries of class and popularised the revolution as a project of national liberation.

People's war was grounded in two fundamental premises. First, all of the material and spiritual wealth of human society is created by the large majority of the labouring people who are the natural masters of society ('the people, and the people alone, are the motive force in the making of world history'); second, all social phenomena and processes, including war, must conform to the fundamental interests and aspirations of the masses in order to be just and reasonable. On these grounds, all wars can be divided into two categories: 'righteous wars' (zhengyi zhanzheng) that serve the people's interests and 'unjust wars' that harm them. Righteous wars will obtain the endorsement and support 
of the people. Not only will people throw themselves into non-military struggle, but also energetically participate in military struggle. In this way, people's war possesses a mass quality and totalising quality. Conversely, people often resist and oppose unjust wars. For example, in both Korea in 1950 and Vietnam in 1973, the United States finally had to withdraw from these unfinished wars as a result of the popular belief at home that they were unjust.

In its own revolutionary struggle, the CCP and the People's Army attempted to preserve maximal distance and independence from the command of the Republican government. They did this by engaging in people's war, i.e. investing in the people's lives, infrastructure, and productive capabilities in its base areas. Under army leadership, the large production campaign at South Muddy Bend (nanniwan) significantly improved the living conditions, and reduced the burdens of people living there. ${ }^{6}$ The contrast with the Nationalist Party could not be clearer: the People's Army was more than just a fighting unit, but also a propaganda team, a production team, and a tractor planting the seeds of the future rolled into one. By establishing a relationship of flesh and blood with the local people, the People's Army was full of vital force. The Japanese invaders found themselves trapped in a people's military struggle behind enemy lines. As Mao said in 'On Protracted War:' 'The mobilisation of the common people throughout the country will create a vast sea in which to drown the enemy, create the conditions that will make up for our inferiority in arms and other things, and create the prerequisites for overcoming every difficulty in the war.'

This discourse of people's war supplied the CCP with an explanation for its victory over both the Japanese and the Nationalist Party, and a source of legitimacy. It was able to defeat armies with superior military and technological support on the basis of its magic weapon-the support of the people (see Balso's essay in the present volume). In political propaganda, the CCP accused the Nationalist Party of 'representing the reactionary classes' and 'opposing the people', and labelled Chiang Kai-shek an 'enemy of the people.' Mao's theory of people's war contrasted the Nationalist Party's corruption and alienation from the people with the political superiority and mass-based support of the CCP.

\section{Political Legacy}

People's war was not only a military strategy, but also a theory of political party organisation and ideology. Ultimately, the theory of people's war determined the nature of the CCP.

From the Communist Manifesto onwards, socialist revolutionaries have explored how to establish a revolutionary party organisation. In What is to be Done?, Lenin expounded the idea that the Communist Party must control the machinery of public opinion to impart proletarian consciousness to the proletariat, and transform disparate workers into an organised force aware of their own power. Mao's theory of people's war was developed on the basis of his insight into the conditions faced by the CCP. As early as Mao's 1927 'Report on an Investigation of the Peasant Movement in Hunan' he realised that the crucible of the Chinese Revolution was the education of the peasantry and that the revolutionary process depended on an alliance between peasants and workers. From Mao's first mention of his famous phrase 'political power grows out of the barrel of 
a gun' at the emergency meeting of the CCP Central Committee to address the question of agrarian revolution and armed struggle on 7 August 1927 in Hankou, the theory of people's war began to ferment until it achieved final form.

During the revolutionary process, Mao gradually realised that the CCP could not separate itself from the practical conditions of Chinese reality. Although the CCP came into being as part of the international communist movement, it became a distinct party by absorbing into itself the cultural traditions of Chinese civilisation. In retrospect, it is clear that the CCP did not mechanically replicate the definitions of Marxism, Leninism, and Stalinism, but supplemented and refashioned them through Confucian moral norms and China's dynastic historical experiences. Mencius's phrase 'whoever wins the people's hearts, wins the world' (de minxin zhe de tianxia) was proven in the victory of people's war. For Mencius and Mao, the people's heart is the most formidable weapon.

To this day, people's war is one of the historical foundations of the legitimacy of the CCP government. In the revolutionary years, the Communists who engaged in people's war cultivated an exceptional work style, disciplined themselves through arduous struggle, and behaved with integrity and honesty. But without the motivational horizon of people's war, this moral resource has been gradually lost. Armed with the concept of the people, Mao Zedong transformed the CCP, achieved Revolutionary victory, blazed a new path for China, and created history. But the world has changed since Mao's death. In China today, who is still capable of mobilising the people in their exalted name? 
This text is taken from Afterlives of Chinese Communism: Political Concepts from Mao to Xi, edited by Christian Sorace, Ivan Franceschini and Nicholas Loubere, published 2019 by ANU Press, The Australian National University, Canberra, Australia.

doi.org/10.22459/ACC.2019.28 